Quirke, V (2004)

French biomedicine in the mirror of America.

Studies in History and Philosophy of Science Part C: Studies in History and Philosophy of Biological and Biomedical Sciences, 35 (4). pp. 765-776.

10.1016/j.shpsc.2003.12.019

This version is available: http://radar.brookes.ac.uk/radar/items/117e7e77-a4cb-c50a-c5bc-a66bb44b9414/1/

Available on RADAR: March 2014

Copyright (C) and Moral Rights are retained by the author(s) and/ or other copyright owners. A copy can be downloaded for personal non-commercial research or study, without prior permission or charge. This item cannot be reproduced or quoted extensively from without first obtaining permission in writing from the copyright holder(s). The content must not be changed in any way or sold commercially in any format or medium without the formal permission of the copyright holders.

This document is the author's final version of the journal article. Some differences between the published version and this version may remain and you are advised to consult the published version if you wish to cite from it. 


\title{
French biomedicine in the mirror of America
}

\author{
Viviane Quirke
}

Centre for Health, Medicine and Society: Past and Present, Oxford Brookes University, Oxford, UK

\section{Inventer la biomédecine: la france, l'amérique et la production des savoirs du vivant (1945-1965)}

Jean-Paul Gaudillière, La Découverte \& Syros, Paris, 2002, pp. 392, Price F 219,75 paperback, ISBN 2-7071-3607-7.

\section{Inventer la biomédecine in historiographical context}

'Among Western European nations France has been known for its anti-Americanism'. So opens Richard Kuisel's Seducing the French (Kuisel, 1993, p. i). ${ }^{1}$ Rooted in a rich body of writing dating back to the 1920s and 1930s, this anti-Americanism has largely been the prerogative of left-wing intellectuals. However, Kuisel, an American historian living and studying in France, has also observed that 'recently, in contrast, [France ... .] seemed to succumb to the American way of life' (Kuisel, 1993, p ix). This observation led him to write Seducing the French in an attempt "to understand better how France became modern or "Americanized", and yet remained French':

If we [Americans] were a mirror before which the French saw themselves, we were also a tangible social landscape that the French experienced. If anti- (and pro-) Americanism was, at one level, a reflectio of French thought about personal identity and the future, it was also a confrontation with the content of postwar America. America and Americanization were realities that the French-politicians, visitors, or those surveyed by opinion polls - had to face after 1945. The United States was a superpower that provided security and exerted enormous influenc on postwar Western Europe. Americanization was a process of economic 
modernization, and America was the frst consumer society and possibly a harbinger of Europe's future. (Kuisel, 1993, pp. xi-xii)

The Americanisation of France occurred as through a number of postwar encounters between the two nations brought on by the economic and political imperatives of reconstruction and the Cold War, from the Blum-Byrnes accords, NATO, the Marshall Plan and the Schuman and Pleven Plans, to American military intervention in Indochina. Describing how the French biomedical complex was created in the 'mirror of America' as a result of an increasing number of transatlantic exchanges of men, materials, and ideas (pp. 32-3, 376), ${ }^{2}$ Inventer la biomédecine therefore joins the mainstream literature on the impact of America on postwar France. In addition to Seducing the French, this literature includes several articles in a special issue of French Historical Studies on France since 1945 (Mulholland, 1991), and The United States and the making of postwar France (Wall, 1991). A growing proportion of the historiography, however, is concerned with the history of science and technology. Focusing chief y on atomic policy and nuclear power (Goldschmidt, 1964; Weart, 1979; Pace, 1991; Hecht, 1998), it shows how the French postwar nuclear programme became central to French national identity and was often def ned in opposition to America despite it being a continuation of wartime collaborations between American, British, Canadian, and French scientists. ${ }^{3}$

In contrast, relatively little has been written about the impact of the United States on the French biomedical sciences. In their introduction to the co-edited volume Les sciences biologiques et médicales en France, 1920-1950, Debru and Gayon justify the study of science in a French national context in terms of a social, as opposed to intellectual history. Such a history, they argue, is not only better able to show how the rise of the nation states inf uenced scientif c practices, it can also account for national trends, in particular the stagnation of French science after the First World War (Debru \& Gayon, 1994, pp. 11-12). However, although Les sciences biologiques et médicales includes two chapters on English views of French physiology (the title of one, 'the other side of the mirror', using the mirror metaphor once again) and although it recognizes the importance of Franco-American collaboration in genetics, the work largely eschews the question of foreign, more specif cally American inf uences on French biological and medical sciences.

Until now, this question of American inf uence has almost always been addressed in histories of the Rockefeller Foundation (Zallen, 1989, 1991; Picard, 1999). Long acknowledged as the predominant 'modernising' inf uence on the natural sciences in the western world, ${ }^{4}$ the Rockefeller Foundation had special ties to France since the early twentieth century. These histories generally conclude that its inf uence on French science was considerable, particularly after the Second World War, through the Foundation's equipment and conference grant programmes (Mulholland, 1991).

\footnotetext{
2 All page references are to Inventer la biomédecine unless otherwise stated.

3 See Hecht (1998), Ch. 1; Goldschmidt (1964), Ch. 2.

${ }^{4}$ For a critical appraisal of this view in relation to molecular biology, see Abir-Am (1982).
} 
Although French scientists maintained their independence and pursued their own agenda, their need to share equipment, along with new links forged between scientists at conferences, encouraged group efforts and teamwork in a way that might not have been possible before - under what Rockefeller off cials saw as the French tendency 'for isolated, unintegrated research efforts' (Zallen, 1989, p. 57). This new, collaborative way of doing science contributed to the rise of new multi-disciplinary approaches of the kind that blossomed in the early 1960s with the French Nobel Prize-winning work on genetic regulation (Debru \& Gayon, 1994, p. 16). ${ }^{5}$

It is interesting to note that much of the literature so far cited has American authors; French historians have tended to avoid the issue of American inf uence on their scientif $\mathrm{c}$ and technical culture, which perhaps more than other area of culture has become central to French identity (Guerlac, 1964; Paul, 1985; Hecht, 1998). This may not only ref ect the American fascination with the French fascination with America (Hecht, 1998, p. 39), but also the ambiguous feelings of French cultural élites towards the United States. Inventer la biomédecine breaks with this tradition; it tackles the issue of the American legacy in the French biomedical sciences headon. According to Gaudillière, this legacy consists of the creation of a French biomedical complex, which he def nes by analogy with the American 'scientif c-militaryindustrial complex' that emerged during the war (p. 15), and with the biomedical complex that followed (p. 16). Gaudillière's study is based on an extensive body of English and French-language literature on the biomedical sciences, including his own publications in the feld, and on research he has carried out in French and American archives. This is the frst respect in which Gaudillière's book is an important contribution to mainstream as well as to more specialist historiography. It is all the more important that in Franco-American relations (including scientif $\mathrm{c}$ and technical relations) lies an explanation of the fundamental socioeconomic and cultural changes of the postwar years. In the case of France these have been referred to as the "new French Revolution' (Kuisel, 1993, pp. ix, xii), or ' Les Trente Glorieuses' (p. 12). Gaudillière concludes, as have many authors writing about the Rockefeller Foundation, that while American inf uence was crucial it also had its limitations. However, unlike these authors, Gaudillière takes this analysis one step further. At one level, he shows how French scientists were not only actively engaged in the transfer of instruments, materials, and results, which they selected to suit their own research interests (p. 374), but also in the production of images of America to be used in the reconstruction of French science after the war (p. 376). At another level, he examines how instruments, techniques, and artefacts - such as the ultracentrifuge, the electron microscope, radioactive isotopes, and a variety of biological and chemical molecules - were imported across the Atlantic, and were subsequently adapted and transformed by local French scientif c networks. As 'boundary objects', these contributed to making the new f eld of natural knowledge that became 'biomedicine' in a French context (Starr and Griesemer, 1988; Golinsky, 1998).

\footnotetext{
${ }^{5}$ For a history of collaboration between biomedical researchers and pharmaceutical companies in Britain and France, see Quirke (1999), and forthcoming.
} 
The second way in which Gaudillière's book represents an important contribution is in his detailed approach to the subject, which privileges the study of the material culture of laboratories. Gaudillière's approach is double. In the frst instance he uses a social constructivist approach attributed to the Social Studies movement. This movement has highlighted the role of controversies, of material culture, and of historical context in the development of scientif c knowledge (pp. 17-18). However, I would add that this movement has been greatly enriched by cross-national readings, in particular of the French philosopher Michel Foucault (see, for example, Jordanova, 1995), and by multi-disciplinary collaborations between French and English-speaking sociologists, philosophers, and historians of science and medicine. These have been the product of an increasing number of transatlantic as well as cross-Channel exchanges (for example Latour and Woolgar, 1986; Callon, 1987; Hughes and Pinch, 1987). Thus, Gaudillière's choice of the title Inventer la biomédecine not only ref ects the book's content, but also situates it within a body of work on related topics using similar approaches (such as Harden, 1980).

In a second instance, Gaudillière adopts a micro-analytical approach, one which has gathered pace in recent years. ${ }^{6}$ According to him, the interest of the detailed, local studies upon which Inventer la biomédecine is based lies not so much in that they avoid the pitfalls of wide-sweeping generalisations, but rather in that they allow the close investigation of the processes involved in the construction of new scientif c facts, artefacts, and research felds (p. 18). A striking illustration of this is given in the chapter on Pierre Lépine, who directed the virology department at the Pasteur Institute. Gaudillière describes how the study of viruses - such as the polio virusin this department depended almost entirely on the transfer of information, protocols, plans, and biological materials from American laboratories during and after the Second World War. However, Gaudillière also shows how Lépine's adaptation and application of the ultracentrifuge was steeped in the Pasteurian tradition of bacteriological research associated with the production of vaccines. Therefore, unlike his American counterparts Wendell Stanley and Jonas Salk, Lépine was neither a biophysical instrument builder, nor a biological expert providing consultancy services for a frm or foundation. Rather, he was a 'one man band' (p. 146), who collected materials, designed experiments, organised trials, and supervised the construction of a production plant. Nevertheless, like his American counterparts and like his colleagues at the Pasteur Institute engaged in the study of micro-organisms, through the use of physical instrumentation Lépine took an active part in the development of a new vision of viruses as macromolecules (p. 117). Thus, by focusing on individual case studies ranging from the production and evaluation of antibiotics (ca. 1945), to the collaborative networks and research practices of biochemists (ca. 1965), Gaudillière shows how after the Second World War French biomedicine was 'invented' in the laboratory and in the clinic as a result of the transfer of skills, apparatuses, and results from America to France, but also, in the case of molecular biology (Ch. 7), back across the Atlantic in a reciprocal system of exchange.

\footnotetext{
${ }^{6}$ For an example in relation to the history of molecular biology, see de Chadarevian, (2002).
} 
Inventer la biomédecine loosely follows the standard chronological order of political histories: the period of post-war reconstruction (1945-1948), in which the principal research agencies were set up; the parliamentary regime that followed (19491958), which Gaudillière characterises as a period of consolidation; and f nally the new authoritarian republic under De Gaulle (1958-1967), in which increased funding for research was matched by the growing power of the State. However, Inventer la biomédecine does not follow the linear structure of institutional histories such as those by, for example, Picard (Picard, 1990). Instead, as the author describes it himself, it is a 'mosaic' (pp. 20-1). Although it might be possible to justify such a structure by arguing that the French biomedical complex was itself a mosaic (something Gaudillière does not actually do, but which I attempt below), it has the effect of presenting a fragmented picture of French biomedicine.

\section{French biomedicine as a 'mosaic'}

In an article on the Pasteur Institute and the development of microbiology in France, Ilana Löwy, a long-standing collaborator with Gaudillière, used the term 'mosaic' to describe the Pasteur Institute, the largest institute of biological and medical research in France before the Second World War (Löwy, 1994). It could thus be argued that this description is valid, at least until the war, for the French system as a whole, which has been described as 'hopelessly fragmented' in terms of its politics (Mulholland, 1991, p. 3), and 'unintegrated' in terms of its science (Zallen, 1989, p. 57). Löwy proposed that from its very beginning the Pasteur Institute was 'a complex mosaic of heterogeneous material and social practices' (Löwy, 1994, p. 664). However, she also maintained that the circulation of micro-organisms, as a specif c set of objects and practices that 'cemented' the mosaic together, gave internal coherence to the Institute and linked it with external sites and with extra-mural social groups.

After the war, the inf uence of the Pasteur Institute remained considerable. ${ }^{7}$ However, it ceased to be an exception, and became part of the constellation of institutions that made up the French biomedical complex (p. 34). One might, therefore, hypothesize that Gaudillière's book imitates its object and that, consequently, it too is a mosaic. What appears to have cemented the mosaic of French biomedicine together are the molecular tools and concepts that French biologists and clinicians came to share (pp. 12-13), and the collaborative research practices they adopted through contact with their American colleagues, despite continuing tensions between the laboratory and the clinic. In the Prologue, Gaudillière describes the visits made by French scientists to the United States at the time of the Liberation, in particular those of Louis Bugnard, director of the Institut National d'Hygiene (INH) created under Vichy, and Jacques Monod, a biochemist from the Pasteur Institute and Rockefeller

\footnotetext{
${ }^{7}$ On its place in the French school of molecular biology, see Morange (1998), pp. 162-163.
} 
grantee. These visits were facilitated by the presence of Louis Rapkine at the head of the French scientif c mission in New York, and from 1944 in London.

Chapter one describes the research on and production of antibiotics, especially penicillin, which was studied through the 'missions de la pénicilline' to Britain and to the United States, and which underpinned the postwar reconstruction of the biological and medical sciences in France, as it did in many other Western countries. Chapter three focuses on the viruses and the ultracentrifuge used by Pierre Lépine at the Pasteur Institute to develop an alternative to Jonas Salk's polio vaccine. Chapter four deals with the electron microscope, and its role in the controversy about the viral origins of cancer that was played out in institutions such as the Insitute for cancer research in Villejuif. Chapter seven concerns the colibacillus and other molecular systems in the work of Jacques Monod. Chapter eight is on 'boundary objects' such as RNA and their place in networks of French biochemists. Other chapters include investigations of the role of the State (Chapters two and eight), and studies of clinical genetics and medical statistics (Chapters f ve and six).

Throughout, Inventer la biomédecine pays special attention to the transfer of American instruments, materials, and results, and compares research practices in France and America. However, while the Prologue and the frst chapter fow one from the other, following an obvious chronological order linking them to the Second World War and post-war reconstruction, the rest of the book jumps from one topic to the next. It thus becomes diff cult to keep track of the chronology laid out on $p$. 20. In his introduction (pp. 7-21) and general conclusion (pp. 369-381), Gaudillière draws out what he sees as the broad characteristics of the French biomedical complex. In the two sections that follow, I summarize and discuss his arguments about the nature and rise of French biomedicine, arguments which are central to Inventer la biomédecine.

\section{The rise of the French biomedical complex}

The frst of these arguments is that French biomedecine was invented between 1945 and 1965 as part of the postwar reconstruction of France, and was directly inspired by the American biomedical complex (p. 16). However, what actually comprised biomedicine was hotly contested, particularly in concerns over the balance to be achieved between experimental, clinical, and social medicine (p. 14). Similarly, of the different actors, whether biologists, clinicians, public health off cials, or managers of pharmaceutical companies (p. 15), it was not obvious at the outset who would come to play the greatest role in building French biomedicine.

Of all these actors, Picard has drawn historians' attention to the new generation of clinicians (Picard, 1994). After a frst, failed rendez-vous between medicine and biology in 1945, at last they succeeded in creating physio-pathological laboratories inside French hospitals under the leadership of Robert Debré, who was active in research as well as in the political arena (Picard, 1994, pp. 338-340). The rapprochement between biology and medicine that was embodied in these laboratories, and which led to the new entity of 'biomedicine', a term coined in the early 1960s, 
culminated in the foundation of the Institut National de la Santé et de la Recherche Médicale (INSERM) in 1964. However, Picard has argued that inspired by the model of the British Medical Research Council (MRC) that Rapkine introduced to French visitors through the Mission Scientif que, INSERM has leaned towards an experimental rather than clinical interpretation of medicine (ibid., pp. 342-343).

By contrast, and perhaps in order to explain such an outcome, Gaudillière privileges the role of biologists among all the men in white coats-les 'hommes en blouses blanches', of which he was one himself before becoming a historian (p. 17)-who participated in the construction of French biomedicine after the Second World War. According to Gaudillière, 1945 was not a 'failed rendez-vous'. On the contrary, it was a double rendez-vous, between French and American science and technology as well as between biology and medicine. To Gaudillière, the period of the Liberation and of postwar reconstruction presented favourable conditions for the expansion of the biological sciences, sciences which in the era of Big Science benef ted from the new role of the state as provider of healthcare (p. 371). This period was therefore crucial to the emergence of French biomedicine, in which the biological has come to dominate over the medical. Thus, between 1945 and 1965, the relationship between hospitals and biological laboratories was altered, and the biological laboratory became the key site of production of medical knowledge (p. 9). Such a reversal in the polarity of the system was made possible by the molecularisation of biology and medicine (Abir-Am, 1997; de Chadarevian and Kamminga, 1998), which meant that biologists and clinicians came to share the same research tools, and the same molecular vision of life (pp. 12-13).

Thus, although Gaudillière alludes to a number of collaborative relationships between French and American scientists that pre-dated the Second World War, often thanks to Rockefeller grants, his focus on the postwar period leads him to play down the continuities with the interwar period. This contrasts with Debru and Gayon's argument that between the wars the ground was laid for the renewal of several biological and medical disciplines after the Second World War (Debru \& Gayon, 1994, pp. 11-12), an argument picked up by Morange in relation to the French school of molecular biology (Morange, 1998, p. 151). Gaudillière also downplays the wartime experiences of French scientists, both in exile and under Vichy, which are nonetheless mentioned in a number of his case studies. Finally, his focus on the biological, rather than the medical, leads him to play down the role of clinicians. However, when attempting to distinguish the French biomedical complex from its American counterpart, he brings French clinicians to the fore.

\section{The nature of the French biomedical complex: French biomedicine in comparative perspective}

In addition to examining the impact of American inf uence, Gaudillière highlights the particularities of the French context, enabling him to def ne the French biomedical complex through comparing and contrasting it with its American counterpart. Among these particularities, he emphasizes the role of the 'néoclinicien', who was more 
indifferent to America than his biological colleague (p. 376), and who acted as a brake on the transfer of methods, especially medical statistics, from the Englishspeaking world to France. These methods accompanied the shift in emphasis from infectious to chronic diseases in public health debates, and played a crucial role in the organisation of the modern, randomized clinical trial (Berridge, 1998; Matthews, 1995). Thus, although this new generation of clinicians were more attentive to the laboratory sciences than their predecessors (the 'grand cliniciens'), in the period under consideration, they remained wary of medical statistics (judging them 'too abstract', p. 370), of randomized trials ('too bureaucratic'), and of a chemical approach to therapy ('too reductionist'). This interesting conclusion would have merited further development, for the molecular tools and vision which French clinicians and biologists came to share in the age of biomedicine coincided with the rise of chemotherapy (p. 370), of which neo-clinicians nevertheless remained suspicious (p. 372).

Gaudillière also identif es particularities related to the organisation of science in France. He points out the relative absence of charitable organisations and philanthropic societies, and, by contrast, the overwhelming presence of the State. These particularities enable Gaudillière to highlight some intriguing paradoxes. To the French observer, the American situation is curious in that it has combined loose administrative control of research with massive investments and a powerful regulatory framework through agencies such as the Food and Drug Administration (p. 316). Conversely, in France, the State has lent its structures and practices of central management to the organisation of the biomedical complex, but has paid little attention to therapeutic intervention and to public health. One of the most important consequences of the centralized and state-controlled nature of the French biomedical complex, def ned in contrast with the American biomedical complex, has been that pharmaceutical companies have been relegated to its margins. Gaudillière contrasts this with the 'Anglo-Saxon' model (p. 112), in which industry is a much more powerful partner. Another consequence is the lesser importance that has been accorded to clinical trials and to medical statistics. This time, Gaudillière contrasts France with Britain, where the National Health Service provided a fertile ground for the development of trials and statistics, and where statisticians have played a key role in their capacity as experts advising government on health policy (pp. 244-245, 377-380).

Britain, therefore, is not absent from Gaudillière's analysis, although it is often subsumed under the epithet 'Anglo-Saxon'. No doubt this is an actors' category, but Gaudillière does not appear to acknowledge it as such. It is a pity, for his description suggests that in the immediate post-war period at least, the rise of French biomedicine was the product of a triangular relationship between France, the United States, and the United Kingdom, although in a Cold War context the balance shifted in favour of transatlantic, rather than cross-Channel exchanges. Exploring this relationship in greater depth might have provided some very interesting insights into the internal dynamics of the victorious Allied camp, and its links with the growth of biomedicine in the postwar period (for a tri-partite comparison in relation to molecular biology, see Abir-Am, 2001).

Also missing from Inventer la biomédecine is a clear sense of the role of the 
French pharmaceutical industry. Although Gaudillière recognizes this omission, and accounts for it by explaining the diff culty of access to company records (p. 380), he makes little use of company histories and other secondary sources that might have been helpful in his conclusion. The history of Rhône-Poulenc's neuroleptic drug chlorpromazine, in particular, would have provided him with a useful counterexample (see Caldwell, 1970, Swazey, 1974, and Baverey, work in progress). Indeed, chlorpromazine helped to establish ideas about the chemical aspects of mental illness, created a new branch of psychology and/or pharmacology — psychopharmacologyand transformed psychiatric care not only in France, but also in the United States, despite the strength of its psychoanalytical tradition. Therefore it represents one instance in which French clinicians (the naval surgeon Henri Laborit, and the psychiatrists Jean Delay and Pierre Deniker) were the driving force behind a chemical approach to therapy. Moreover, with support from the French chemical group RhônePoulenc - which far from being relegated to the periphery, was at the centre of the innovation process with chlorpromazine - they successfully exported this approach, f rst from France to Britain via the French f rm's British subsidiary, May \& Baker. America quickly followed, in a move facilitated by the French group's relationship with the American pharmaceutical company SmithKline\&French (see Swazey, 1974, Ch. 7; also Quirke, 1999, pp. 237-244). The example of chlorpromazine would have been all the more appropriate in that it presents yet another instance of a reversal of direction in translatlantic exchanges, the best known example being molecular biology (Ch. 7, esp. pp. 276-289), on which Gaudillière wrote his doctoral thesis in 1991 (Gaudillière, 1991).

\section{The singular case of molecular biology?}

Unlike one of his actors, the biochemist Georges Cohen (pp. 270-271) who described the 'transatlantic ballet of scientists' that began in 1946 with the frst Cold Spring Harbor symposium following the war (Cohen, 1986), and unlike Abir-Am, who situates the rise of molecular biology between 1938 and 1973 primarily within an international and transdisciplinary space (Abir-Am, 1992), Gaudillière distinguishes between two phases in the history of transatlantic exchanges in molecular biology. On his account, the direction of these exchanges was reversed from France to America after the 1961 Cold Spring Harbor meeting on the metabolic regulation of micro-organisms (p. 276). This was the frst symposium which François Jacob and Jacques Monod (who were jointly awarded the Nobel Prize for Physiology or Medicine with André Lwoff in 1965) attended together. Between 1961 and 1965, their manuscripts and publications covered the desks of American biochemists and geneticists. Such a reversal in the direction of transatlantic exchanges was unusual not only within the context of the Pasteur Institute, but within the French context as a whole (p. 278). Gaudillière attributes the success of the experimental system set up by Monod and his group in the late 1950s and early 1960s that led to the discovery of messenger RNA partly to fruitful 'intrapastorian' collaborations ( $p$. 283), and partly to well-established transatlantic networks. The latter enabled Mon- 
od's group to mobilize resources and information unavailable to other French biochemical laboratories at the time. They also made it possible for the group's results to gain prompt acceptance in the international (mostly Anglo-American) arena, even though they retained the mark of the local context in which they were produced (p. 288).

Alongside de Chadarevian's study of the Laboratory of Molecular Biology in Cambridge, which between the 1950s and 1960s became an 'obligatory passage point' for would-be molecular biologists from America and elsewhere (de Chadarevian, 2002, p. 2), Inventer la biomédecine prompts important questions about the postwar reconstruction of European sciences, and about the place of molecular biology in this reconstruction. Why was the direction of transatlantic exchanges reversed in molecular biology, not only from France, but also from Britain to America, at a time when the United States were the centre of 'molecular biology's rise to power' (AbirAm, 1997, p. 516)? Was this simply an early sign of what was to come in the postCold War period - the 'global village' of the biotech era — or was it something more? Despite the importance of international exchanges and networks in the making of the new discipline, these reversals suggest that molecular biology offered a privileged, although not unique, site for the 'Europeanisation' of the biomedical sciences, at a time when much of Western Europe was being exposed to American power and inf uence. Perhaps an accidental side-effect of, as well as a reaction against the muchdecried "brain-drain", this Europeanisation was symptomatic of the political and cultural meaning with which molecular biology, more than any other discipline, became invested in the post-war/Cold War period. This led to the creation of the European Molecular Biology Organisation (ЕмBO) in the 1960s, followed by the European Molecular Biology Laboratory (EMBL) in the 1970s. In both these institutions French and British molecular biologists played an important role, the latter at a time when Britain was entering the fold of the European Community. Nevertheless, if the plan to build a European laboratory of molecular biology succeeded, it was also because it received the backing of the United States, which in the wake of Sputnik and the Cuban crisis saw EMBO and EMBL as a means of strengthening Western European science (on this see de Chadarevian, 2002, pp. 254-257, 325-333; also Strasser, 2002, and Krige, 2002).

Although it does not address these questions, Inventer la biomédecine has the great merit of presenting a dynamic picture of the development of molecular biology in France, and of situating the discipline within the wider context of French biomedicine. I therefore have little doubt that it will stimulate many debates about the rise of national biomedical complexes, about the role of different categories of actors, and about the relative importance of different scientif $\mathrm{c}$ disciplines and medical specialisms. I look forward to it being translated into English, for the description it offers of America 'in the mirror of France' will be a most welcome addition to the 'Anglo-Saxon' literature on the subject. It might also provide a useful model for similar histories, most notably of the rise of the British biomedical complex, which, I suspect, would present many parallels with the French experience. 


\title{
6. Uncited reference
}

\author{
Burian et al., 1984
}

\section{Acknowledgements}

\section{My thanks go to Pnina Abir-Am, Soraya de Chadarevian, and Jean-François Picard} for their helpful comments on an earlier version of this essay.

\section{References}

Abir-Am, P. G. (1982). The discourse on physical power and biological knowledge in the 1930s: A reappraisal of the Rockefeller Foundation's 'policy' in molecular biology. Social Studies of Science, $12,341-382$.

Abir-Am, P. G. (1992). From multidisciplinary collaboration to transnational objectivity: international space as constitutive of molecular biology. In E. Crawford, T. Shinn, \& S. Sörlin (Eds.), Denationalizing science: The contexts of international scientifi practice (pp. 153-185). Dordrecht: Kluwer.

Abir-Am, P. G. (1997). The molecular transformation of twentieth-century biology. In J. Krige, \& D. Pestre (Eds.), Science in the twentieth century (pp. 495-523). Amsterdam: Harwood Academic Press.

Abir-Am, P. G. (2001). Molecular biology in the context of British, French and American cultures. International Social Science Journal, 168, 187-199.

Baverey, S. (work in progress). Ph.D. thesis on the history of chlorpromazine. Strasbourg University.

Berridge, V. (1998). Science and policy: The case of postwar British smoking policy. In S. Lock, L. Reynolds, \& E. M. Tansey (Eds.), Ashes to ashes: The history of smoking and health (pp. 143-163). Amsterdam: Rodopi.

Burian, M., Gayon, J., \& Zallen, D. T. (1984). The singular fate of genetics in the history of French biology, 1900-1940. Journal of the History of Biology, 21, 357-402.

Caldwell, A. E. (1970). Origins of psychopharmacology: From CPZ to LSD. Spingf eld, IL: Thomas.

Callon, M. (1987). Society in the making: The study of technology as a tool for sociological analysis. In W. E. Bijker, T. P. Hughes, \& T. J. Pinch (Eds.), The social construction of technological systems: New directions in the sociology and the history of technology (pp. 83-103). Cambridge, MA: MIT Press.

Debru, C., \& Gayon, J. (1994). Introduction. In C. Debru, J. Gayon, \& J. -F. Picard (Eds.), Les sciences biologiques et médicales en France, 1920-1950 (pp. 9-23). Paris: CNRS Editions.

De Chadarevian, S., \& Kamminga, H. (Eds.). (1998). Molecularizing biology and medicine: New practices and alliances, 1910s-1970s. Amsterdam: Harwood Academic.

De Chadarevian, S. (2002). Designs for life: Molecular biology after world war II. Cambridge: Cambridge University Press.

Cohen, G. N. (1986). Four decades of Franco-American collaboration in biochemistry and molecular biology. Perspectives in Biology and Medicine, 29, S141-S148.

Golinsky, J. (1998). Making natural knowledge: Constructivism and the history of science. Cambridge: Cambridge University Press.

Goldschmidt, B. (1964). The atomic adventure: Its political and technical aspects. Oxford: Pergamon Press.

Harden, V. (1980). Inventing NIH. Baltimore: Johns Hopkins University Press.

Hecht, G. (1998). The radiance of France: Nuclear power and national identity after world war II. Cambridge, MA: MIT Press.

Jordanova, L. (1995). The social construction of medical knowledge. Social History of Medicine, 8 , $361-382$. 
Krige, J. (2002). The birth of EMBO and the diff cult road to EMBL. Studies in History and Philosophy of Biological and Biomedical Sciences, 33, 547-564.

Kuisel, R. F. (1993). Seducing the French: The dilemma of americanization. Berkeley: University of California Press.

Kuisel, R. F. (1996). Le miroir américain, 50 ans de regard français sur l'Amérique. Paris: Jean Claude Lattès.

Latour, B., \& Woolgar, S. (1986). Laboratory life: The construction of scientif c facts. Princeton: Princeton University Press.

Löwy, I. (1994). On hybridizations, networks and new disciplines: The Pasteur Institute and the development of microbiology in France. Studies in History and Philosophy of Science, 25, 655-688.

Matthews, J. R. (1995). Quantif cation and the quest for medical certainty. Princeton: Princeton University Press.

Morange, M. (1998). A history of molecular biology. Cambridge, MA: Harvard University Press.

Mulholland, K. (1991). Introduction. French Historical Studies, 17, (Special issue French science since 1945), 1-5.

Pace, D. (1991). Atomic energy and the ideology of science in post-war France. French Historical Studies, $17,38-61$.

Paul, H. W. (1985). From knowledge to power: The rise of the science empire in France, 1860-1939. Cambridge: Cambridge University Press.

Picard, J.-F. (1990). La république des savants: La recherche française et le CNRS. Paris: Flammarion.

Picard, J.-F. (1994). De la médecine expérimentale (1865) à l'INSERM (1964). In C. Debru, J. Gayon, \& J. -F. Picard (Eds.), Les Sciences biologiques et médicales en France, 1920-1950 (pp. 329-345). Paris: CNRS Editions.

Picard, J. -F. (1999). La Fondation Rockefeller et la recherche médicale. Paris: PUF.

Quirke, V. (1999). Experiments in collaboration: The changing relationship between scientists and pharmaceutical companies in Britain and in France, 1935-1965. Oxford University: D.Phil thesis.

Quirke, V. (forthcoming). Collaboration in pharmaceuticals. Changing relations in Britain and France in the twentieth century. London: Routledge.

Starr, S. L., \& Griesemer, S. (1988). Institutional ecology, translations, and boundary objects: Amateurs and professionals in Berkeley's Museum of Vertebrate Zoology. Social Studies of Science, 19, 387420 .

Strasser, B. J. (2002). Institutionalizing molecular biology in post-war Europe: a comparative study. Studies in History and Philosophy of Biological and Biomedical Sciences, 33, 515-546.

Swazey, J. P. (1974). Chlorpromazine in psychiatry: A study of therapeutic innovation. Cambridge, MA: MIT Press.

Wall, I. M. (1991). The US and the making of postwar France, 1945-1954. Cambridge: Cambridge University Press.

Weart, S. R. (1979). Scientists in power. Cambridge, MA: Harvard University Press.

Zallen, D. T. (1989). The Rockefeller Foundation and French research. Cahiers pour l'histoire du CNRS, $5,35-58$.

Zallen, D. T. (1991). Louis Rapkine and the restoration of French science after the second world war. French Historical Studies, 17, 5-37. 